\title{
Ligga steget före: Barnskötares yrkesomdöme åskådliggjort genom bedömningshandlingar
}

\author{
(Staying one step ahead: \\ The vocational judgement of childminders made visible) \\ Enni Paul \& Camilla Gåfvels \\ Stockholms universitet \& Konstfack, Stockholm, Sverige \\ (enni.paul@specped.su.se)
}

\begin{abstract}
This study explores vocational judgement, which is discernible in the assessment actions of a supervising childminder directed towards upper secondary school students - while interacting with the children - during work-based learning in Sweden. The research aims to identify the characteristics of vocational knowing in terms of judgement, as exhibited in everyday interactions with children, by applying multimodal interaction analysis to two video sequences from different Swedish preschools. The study findings show how vocational judgement - in the form of embodied discernment - is a central aspect of a childminder's vocational knowing. Vocational judgement becomes discernible, for instance, in how supervising childminders are consistently one or several steps ahead of both children and upper secondary school students.
\end{abstract}

Keywords: vocational judgement, vocational knowing, assessment actions, upper secondary school, childcare, pre-school 


\section{Inledning}

Denna artikel undersöker barnskötares yrkesomdöme, så som det kommer till uttryck genom handledande barnskötares bedömningshandlingar riktade mot gymnasielevers interaktion med förskolebarn under arbetsplatsförlagt lärande i Sverige. Bedömningshandlingar (Goodwin \& Goodwin, 1992) kan beskrivas som hur den person som utför bedömningen positionerar sig i förhållande till det som bedöms. I denna artikels sammanhang handlar det om hur en handledande barnskötare vägleder en gymnasieelev under arbetsplatsförlagt lärande. Bedömningshandlingar synliggör vad en expert (yrkeserfaren barnskötare) kan i relation till vad en novis (gymnasieelev) inte kan, i samband med rutinaktiviteter som ingår i barnskötares omsorg och pedagogik.

Förskolan i Sverige riktar sig till barn mellan ett och fem år, och ska erbjuda barnen utveckling, lärande och omsorg (SFS 2010:800). I förskolan arbetar förskollärare, barnskötare och övrig personal (Skolverket, 2019). Barnskötarutbildningen är en utbildning på gymnasial nivå, som kan genomföras inom gymnasieskolans treåriga Barn- och fritidsprogram eller inom ramen för vuxenutbildningen. Förskollärarutbildningen är en 3,5 år lång högskoleutbildning.

Yrkeskunnande - en kunskapsmässig relation till särskilda sätt att "se, göra och vara" (Carlgren \& Nyberg, 2015 s. 28) - har i forskning om förskolan ytterst sällan sin utgångspunkt i barnskötaryrket (Plymoth \& Reimers, 2015). Forskningen tenderar i stället att kretsa kring förskollärares arbete. Förskolans läroplan (Lpfö 18) tillhandahåller inte heller någon beskrivning av barnskötares roll på motsvarande sätt som av förskollärares roll. Det finns därför en påtaglig risk att barnskötare uppfattas som assistenter till förskollärare snarare än som en grupp med ett specifikt yrkeskunnande, vilket innebär en marginalisering av barnskötares yrkeskunnande (Plymoth \& Reimers, 2015). Mot denna bakgrund är den här studiens syfte att synliggöra vad som kännetecknar barnskötares yrkeskunnande i termer av yrkesomdöme, så som det kommer till uttryck i det dagliga samspelet med barn.

Yrkesomdöme kan förstås som förkroppsligad urskiljningsförmåga, vilket för medarbetare i förskolemiljö exempelvis berör löpande avvägningar mellan individ och grupp (Bornemark, 2020). Yrkesomdöme är vidare en central del av yrkeskunnande (Lindberg, 2003). På arbetsplatser är det inbäddat i och del av verksamheten, samt kommer till uttryck i handling (Göranzon, 2007; Janik, 1991; Molander, 1996). Det innebär samtidigt att yrkeskunnande kan vara svårt att uttrycka verbalt, vilket även gäller för omdöme (Bornemark, 2020; Janik, 1991). Yrkeskunnande som inte är artikulerat - såsom just omdöme - men som är centralt i och för yrkesverksamheten, riskerar i yrkesutbildningens skolförlagda verksamhet därför också att hamna i skymundan av formulerad och skolifierad kunskap (jfr Carlgren, 2015). Arbetsplatsförlagt lärande möjliggör samtidigt, genom deltagande $\mathrm{i}$ arbetsuppgifter och handledning, tillägnande av förmåga att 
urskilja och erfara på ett alltmer kvalificerat sätt (jfr Carlgren, 2015; Chan, 2015), vilket främjar utveckling av omdöme; som utvecklas just genom erfarenhet (Bornemark, 2020).

I likhet med förskolemiljön gäller även för många andra yrkesområden att yrkeskunnande innefattar förkroppsligad urskiljningsförmåga i form av omdöme. Förmågan att handla omdömesgillt utvecklas i mötet med praktiken och dess inneboende motsägelser (Göranzon, 2007). Såtillvida kan yrkesomdöme förklaras mot bakgrund av att det inte finns generella regler i alla situationer som uppkommer i yrkesarbetet. I stället behöver yrkesverksamma tolka och bedöma vad som är viktigt $i$ en situation och fatta beslut om hur de ska handla (Göranzon, 2007), till exempel i form av att besluta och ta ansvar för val av material eller metoder (Lindberg, 2003). Dessa beslut är ofta intuitiva och förkroppsligade (Göranzon, 2007). Yrkesomdöme kan kopplas till Aristoteles begrepp fronesis - praktisk klokhet - vilket är sammanbundet med den konkreta situationen och enbart kan komma till uttryck i handling (jfr Nilsson, 2009). Såväl Göranzon (2007) som Bornemark (2020) betonar att sinnligt erfarande utgör grunden för omdöme.

Tidigare forskning visar - som framkommit ovan - att barnskötares kunnande sällan är i fokus (Plymoth \& Reimers, 2015). Pröckl (2020) studerar i sin doktorsavhandling förskollärares förkroppsligade handlingar och praktiska kunnande, bland annat i form av omdöme, samt framhåller att området inte studerats tidigare. Avseende barnskötare har motsvarande område inte beforskats. Vidare finns begränsat med forskning om hur gymnasieelever utvecklar yrkeskunnande under arbetsplatsförlagt lärande (se Lindberg m.fl., 2015; Panican \& Paul, 2019). I en av få studier om handledning under arbetsplatsförlagt lärande framkommer att handledning på förskola för gymnasieelever som går på Barn- och fritidsprogrammet sker antingen som en separat aktivitet " på tu man hand" eller "i farten", där det sistnämnda sker i pågående verksamhet i närvaro av förskolebarn (Mårtensson, 2014). Denna slags handledning tenderar att vara osynlig, vilket innebär att dess betydelse för utveckling av yrkeskunnande riskerar att inte uppmärksammas. För övrigt finns enbart ett fåtal studier som handlar om, eller på något sätt berör, utvecklandet av yrkesomdöme i gymnasial yrkesutbildning (se Gåfvels, 2016; Lindberg, 2003; Tsagalidis, 2008; Tyson, 2017). På senare år har en potentiell konfliktgrund, i förhållande till uttolkning av vad som ska utgöra förskoleverksamhetens kärna, uppstått i form av undervisningsbegreppets inträde i förskolan som ett resultat av förändringar i läroplanen (Lpfö 18), vilket flera studier lyfter fram (se t.ex. Jonsson m.fl., 2017; Olsson m.fl., 2020). Traditionellt har ambitionen att följa barnens intressen - och i samspel upptäcka och undersöka omvärlden - format förskoleverksamheten. Bornemark (2020) framhåller, i relation till omdöme, att det finns en risk att vad som utgör kärnan i förskoleverksamheten - dess vad - går förlorat i och med att målstyrning införs (i efterlikning av skolan och i spåren av undervisningsbegreppet). Icke desto mindre kan förskoleverksamhetens kärna fortsatt uttryckas som att den lokalt situerade 
pedagogiska praktiken tar form i interaktionen mellan pedagoger och barn i nuet (Jonsson, 2013) genom byggande av intersubjektivitet (Dalgren, 2017).

Den grundläggande teoretiska utgångspunkten för denna studie är att samarbete är centralt för mänskligt liv, såväl avseende sociala och kulturella som kognitiva fenomen (Goodwin, 2018, s. 20). Genom sitt funktionssätt - där det samtidiga bygger vidare på allt tidigare - tillhandahåller samarbete en organisationsform för kultur och språk. Med denna utgångspunkt får det som i utbildningsvetenskaplig forskning vanligtvis benämns som teori stå tillbaka för ett deltagarperspektiv där det centrala är hur människor in vivo tillsammans skapar mening in situ (Insulander m.fl., s. 40). Analysen av fenomen - utifrån nämnda utgångspunkt - är därmed att betrakta som "teorimedveten men inte teoridriven" (Insulander m.fl., 2021, s. 136), i betydelsen att teoretiserandet bör komma efter det observerbara, snarare än utgöra ett perspektiv som tillämpas på och styr förståelse av empiri. Goodwin (2018) benämner det samarbete som upprätthåller den rådande sociala ordningen som förkroppsligad kooperativ handling. Ordningen är med detta synsätt ett resultat av ständigt pågående förhandling och omförhandling, i vilken kontext och samspel är föremål för ömsesidig påverkan (Insulander, m.fl., 2021). Analysen i föreliggande artikel har därför skett med ambitionen att ta fasta på blickar, gester, rörelser och kroppspositioner (Filliettaz, 2010; Streeck m.fl., 2011), och inte enbart verbalspråkliga uttryck. Utöver bedömningshandlingar - beskrivna ovan - är samarbetande handlingar (Goodwin, 2018) respektive arbete för att främja intersubjektivitet (Dalgren, 2017) centrala begrepp i analysen. Samarbetande handlingar (Goodwin, 2018) är de i början av detta teoriavsnitt beskrivna mekanismer genom vilka deltagare kumulativt använder tidigare aktörers handlingar som resurs för sina egna handlingar och därigenom lägger grund även för kommande handlingar. Även arbete för att främja intersubjektivitet har samtalsanalytiska (Insulander m.fl., 2021) utgångspunkter - och är därmed närbesläktat med Durantis och Goodwins (1992) formuleringar - samt visar hur deltagare skapar ordning genom sociala handlingar; varigenom normer skapas, bekräftas och befästs.

I linje med resonemanget ovan har studiens frågeställning formulerats som: Vilket yrkesomdöme blir urskiljbart genom handledares bedömningshandlingar - riktade mot gymnasielevers interaktion med förskolebarn under arbetsplatsförlagt lärande - $i$ den vardagliga förskoleverksamheten?

\section{Metod: Multimodal interaktionsanalys av två situationer}

Detta avsnitt redogör först kortfattat för vald metod, följt av empiriskt material, urval och analys. Avslutningsvis problematiseras och diskuteras begränsningar avseende etiska riktlinjer och förhållningssätt i relation till studien. 
Studien använder multimodal interaktionsanalys (Broth \& Keevallik, 2020; Streeck m.fl., 2011), med analytiskt fokus på hur deltagare tillsammans åstadkommer sociala handlingar i interaktion (Insulander m.fl., 2021).

Det använda empiriska materialet består av två separata videosekvenser från olika förskolor. Sekvenserna härrör ur en större datakropp; från två olika fallstudier som berör ett flertal gymnasieprogram och genomförts på uppdrag av Skolverket (Gåfvels \& Paul, 2020; Paul \& Gåfvels, 2020). Gymnasieeleverna i denna studie går andra året på Barn- och fritidsprogrammet. De handledande barnskötarna har varit yrkesverksamma i över 15 år, samt även handlett elever ett flertal år. Barnen i de två sekvenser som transkriberats är tre till fem år gamla.

Urvalsprocessen omfattar totalt fyra (1-4) steg. Det första steget (1) var att ur den större datakroppen särskilja allt material om Barn- och fritidsprogrammets arbetsplatsförlagda lärande. Det andra steget (2) var att identifiera sekvenser som visar handledares bedömningshandlingar när elev och förskolebarn interagerar i den vardagliga förskoleverksamheten. Som ett tredje steg (3) valdes ett antal sekvenser bort på grund av att de var bristfälliga för analysändamål eftersom interaktion saknades, ljudupptagningen var bristande eller att det var uppenbart att betydelsefulla skeenden ägde rum utanför bildrutan. Därefter, i ett fjärde (4) steg, diskuterades urvalet vid en första datasession varvid de två aktuella sekvenserna valdes ut för fördjupad analys. Att valet föll på de två exempel som analyseras motiverades - utöver teknisk kvalitet på inspelningarna - av att (a) de representerar två skilda förskolor, (b) gymnasieeleverna går i årskurs två och kan därmed förväntas ha börjat utveckla yrkeskunnande, (c) de visar inomhusaktivitet som barnen har möjlighet att välja (bort), samt de båda exemplen som analyseras är (d) representativa för den större datakroppens material om Barnoch fritidsprogrammens arbetsplatsförlagda lärande såtillvida att det rör sig om vardagliga situationer i förskolan för handledare, gymnasieelever och barn.

Efter urvalet av de två sekvenserna framställdes representationer i form av detaljerade transkriberingar (se appendix 1 för transkriptionsnyckel) och visuella avbildningar baserade på kamerans bildutsnitt. I det efterföljande analysarbetet låg fokus på samspelet mellan deltagarna, inklusive verbalspråk och kroppsliga dispositioner. Vid den andra datasessionen presenterades och avhandlades såväl analysen som det transkriberade materialet och filmsekvenserna. Detta bidrog till validering av analysen av de två valda sekvenserna. Tabell 1 nedan åskådliggör översiktligt huvudsakliga aspekter som väglett analysen.

De i tabell 1 redovisade aspekterna framträder i transkripten i termer av blickar, gester, verbala uttryck med mera. Responsevidensen (Broth \& Keevallik, 2020) utgörs av de efterföljande leden i all redovisad interaktion, som hela tiden bestämts av förutvarande handlingar. Av läsbarhets- och utrymmesskäl är detta inte (gång på gång återkommande) explicit framskrivet $i$ analysen. Bedömningshandlingar (Goodwin \& Goodwin,1992), samarbetande handlingar (Goodwin, 2018) och arbete för intersubjektivitet (Dalgren, 2017) är framskrivna i analysen. 
Ligga steget före: Barnskötares yrkesomdöme åskådliggjort genom bedömningshandlingar

Tabell 1. Aspekter som väglett analysen.

\begin{tabular}{|l|l|}
\hline Vad har väglett analysen? & Hur har det väglett? \\
\hline $\begin{array}{l}\text { Bedömningshandlingar } \\
\text { (Goodwin \& Goodwin, 1992). }\end{array}$ & $\begin{array}{l}\text { Vad uttrycker handledaren (blick, } \\
\text { kroppsliga dispositioner, verbala } \\
\text { utsagor med mera)? }\end{array}$ \\
\hline $\begin{array}{l}\text { Responsevidens. Hur deltagarnas } \\
\text { handlingar står i relation till hur } \\
\text { föregående handling uppfattas } \\
\text { (Broth \& Keevallik, 2020). }\end{array}$ & $\begin{array}{l}\text { Vad gör eleven som svar på hand- } \\
\text { ledarens handlingar (blick, kroppsliga } \\
\text { dispositioner, verbala utsagor med } \\
\text { mera)? }\end{array}$ \\
\hline $\begin{array}{l}\text { Samarbetande handlingar } \\
\text { (Goodwin, 2018) mellan deltagare. }\end{array}$ & $\begin{array}{l}\text { Vilka samarbetande handlingar tar form } \\
\text { i interaktion (handledare-elev, elev- } \\
\text { barn, handledare-barn med mera)? }\end{array}$ \\
\hline $\begin{array}{l}\text { Arbete för intersubjektivitet } \\
\text { (Dalgren, 2017) mellan deltagare. }\end{array}$ & $\begin{array}{l}\text { På vilka sätt bygger deltagare inter- } \\
\text { subjektivitet i samspelet med varandra? }\end{array}$ \\
\hline
\end{tabular}

I studien har Vetenskapsrådets (2017) forskningsetiska principer följts. Det är undervisningssituationen mellan handledaren och gymnasieeleven som analyseras, aldrig i första hand barnens interaktion eller barnen i sig, även om barnen är centrala för den skildrade interaktion mellan handledare och gymnasielev. Det handlar heller aldrig om vad någon personligen eller privat tycker, tänker eller känner. Vidare förekommer ingen värdering avseende huruvida något är "bra" eller "mindre bra" annat än ett grundantagande om att handledarna besitter ett yrkeskunnande i högre utsträckning än vad gymnasieeleverna gör. Det handlar med andra ord helt enkelt om undervisningssituationer där en handledare agerar i samspel med barn och en gymnasieelev; ett uttalat deltagarperspektiv (Bateman \& Church, 2017). Vidare framträder barnen i artikelns empiri endast i den utsträckning som är nödvändig för att förstå undervisningssituationerna. Informerat samtycke har inhämtats från vårdnadshavare, förskolebarn, handledare och gymnasieelever. Men även om Vetenskapsrådets (2017) forskningsetiska riktlinjer på detta sätt har beaktats finns anledning att uppehålla sig vid vad informerat samtycke innebär för ett barn. Under dataproduktionen (efter att vårdnadshavare gett sitt uttryckliga samtycke och deras barn även gett initialt samtycke) tillfrågades barnen återkommande om de ville vara med, vilket skedde parallellt med riktad uppmärksamhet mot barnens kroppsspråk och stämningsläge (jfr Dalgren, 2017). Samtliga barn bekräftade vid dessa tillfällen sin vilja att delta. Vid ett senare tillfälle - som hypotetiskt ännu kan ligga i framtiden - kan barn som deltagit komma att utmana och ifrågasätta såväl föräldrarnas som sitt eget samtycke till medverkan i studien. För att minimera de forskningsetiska implikationerna av ett sådant hypotetiskt scenario, har långtgående ansträngningar gjorts för att omöjliggöra igenkänning av barn såväl som att försvåra möjligheterna till 
igenkänning även av handledare, gymnasielever och förskolor. Samtliga deltagare i studien har fått fingerande namn, vilket även gäller för förskolorna. De visuella avbildningar som förekommer i transkriberingarna har bearbetats med förenklingar och förändringar för att försvåra igenkänning av för analysen ickebetydelsebärande aspekter av sådant som fysiska kännetecken, frisyrer, kläder och miljö.

\section{Resultat: Pedagogik ingen barnlek på Fiskmåsen eller Daggmasken}

De två utvalda filmsekvenserna härrör från två förskolor med de fiktiva namnen Fiskmåsen respektive Daggmasken. I den följande framställningen är analysen organiserad utifrån de två sekvenserna, som båda handlar om handledares bedömning och vägledning av gymnasieelevers pågående handlingar i en fortgående verksamhet. Den första sekvensen visar en situation där barn spelar Memory och den andra en situation där barn arbetar med leklera. Gemensamt för de båda sekvenserna är att de synliggör en åtskillnad mellan handledarens och gymnasieelevens yrkeskunnande, särskilt gällande yrkesomdöme. Efter resultatframställningen med ett första analyssteg kopplat till respektive sekvens, följer - i ett andra steg - en samtidig analys av de båda sekvenserna.

\section{Fiskmåsen: Värt att komma ihåg vid Memory-spel - möjliggör deltagande!}

Sekvensen utspelar sig efter morgonsamlingen när barnen presenterats för olika stationer med skilda aktiviteter och får välja vad de vill göra. Fyra barn vill spela spel. Gymnasieeleven går med dessa fyra barn till ett stort runt bord. Barnen spelar först ett brädspel och vill sedan byta till Memory, ett kortspel som går ut på att vända på utlagda upp-och-ner-vända spelkort för att på så sätt samla par med identiska bilder av exempelvis redskap, frukt eller djur. När gymnasieeleven lagt ut samtliga kort på bordet påbörjas spelet. Även gymnasieeleven deltar, håller reda på vems tur det är, att reglerna följs, samt svarar på barnens frågor. Ett tjugotal kort ligger på bordet. Efter ett par rundor har inget av barnen hittat något par. 


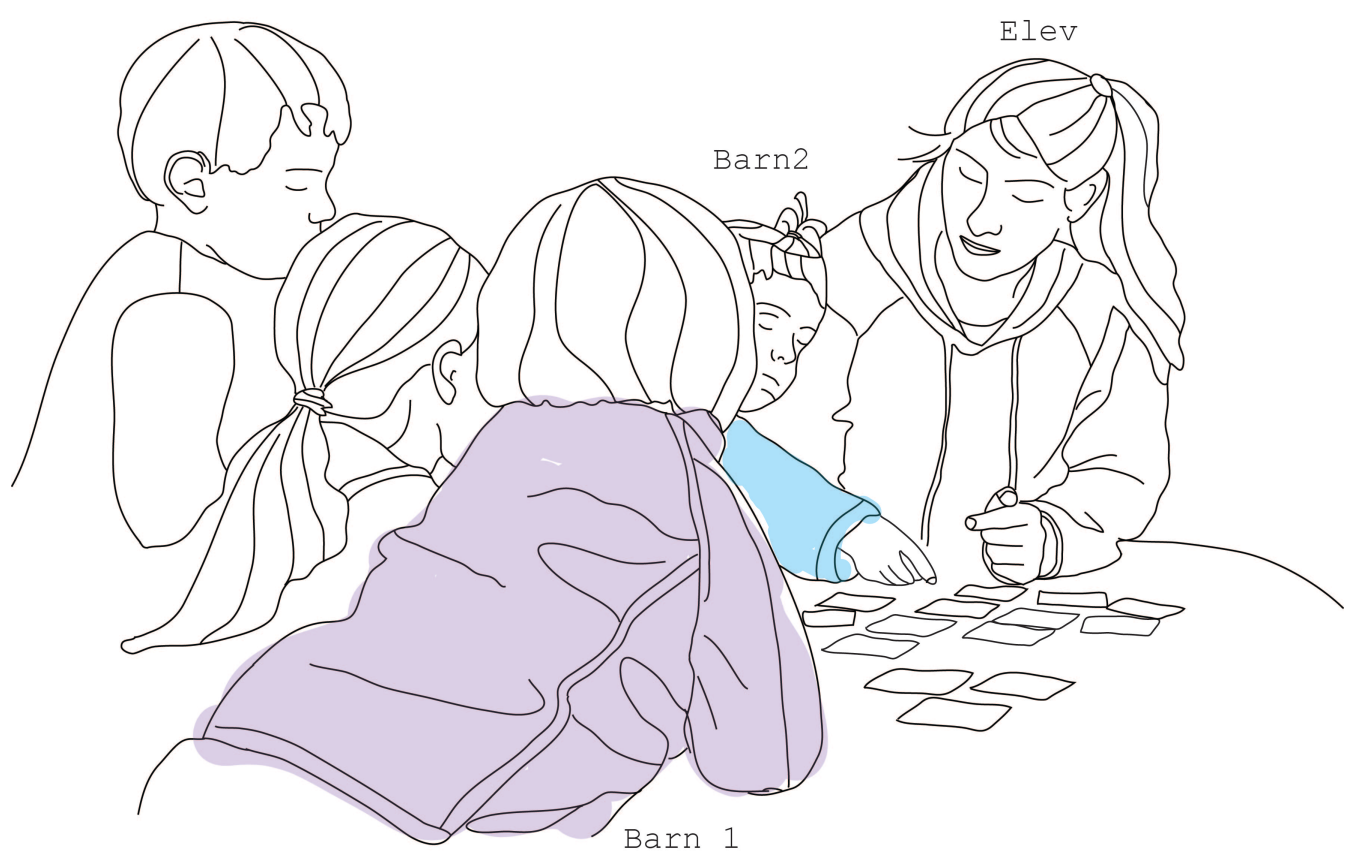

Efter några minuter lämnar två av de fyra barnen bordet, för att gå till en angränsande hall. Gymnasieeleven frågar de två kvarvarande barnen om de vill fortsätta spela. Det vill de båda. Spelet fortsätter. Handledaren sitter på en rullpall i närheten av det runda bordet och är till en början vänd åt ett annat håll samt samtalar med några barn som sitter i en soffa med en bok. Den transkriberade sekvensen börjar då handledaren stannar upp och börjar iaktta Memory-spelandet.

Sekvens 1: Memory på Fiskmåsen

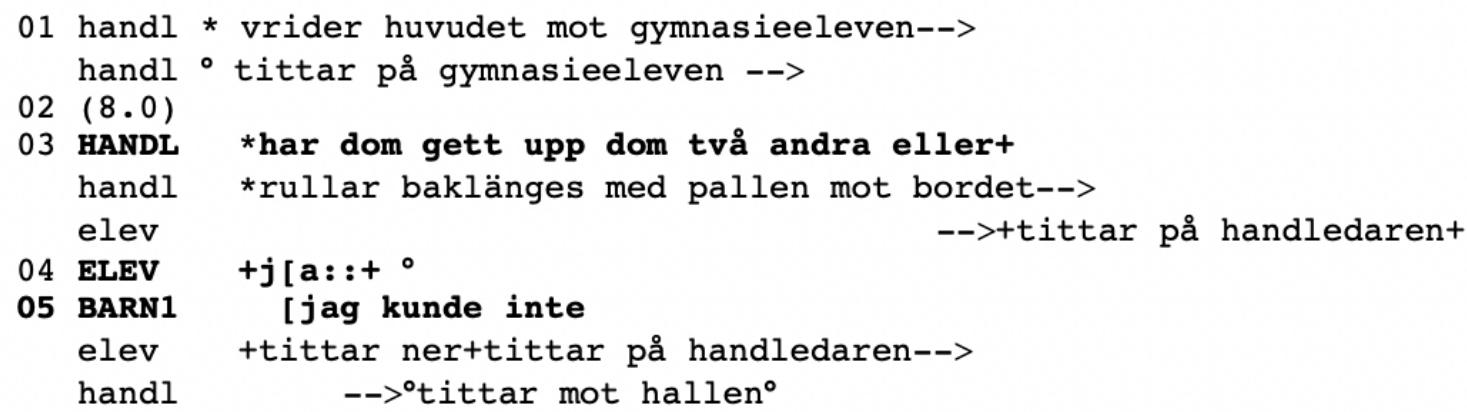


Enni Paul \& Camilla Gåfvels
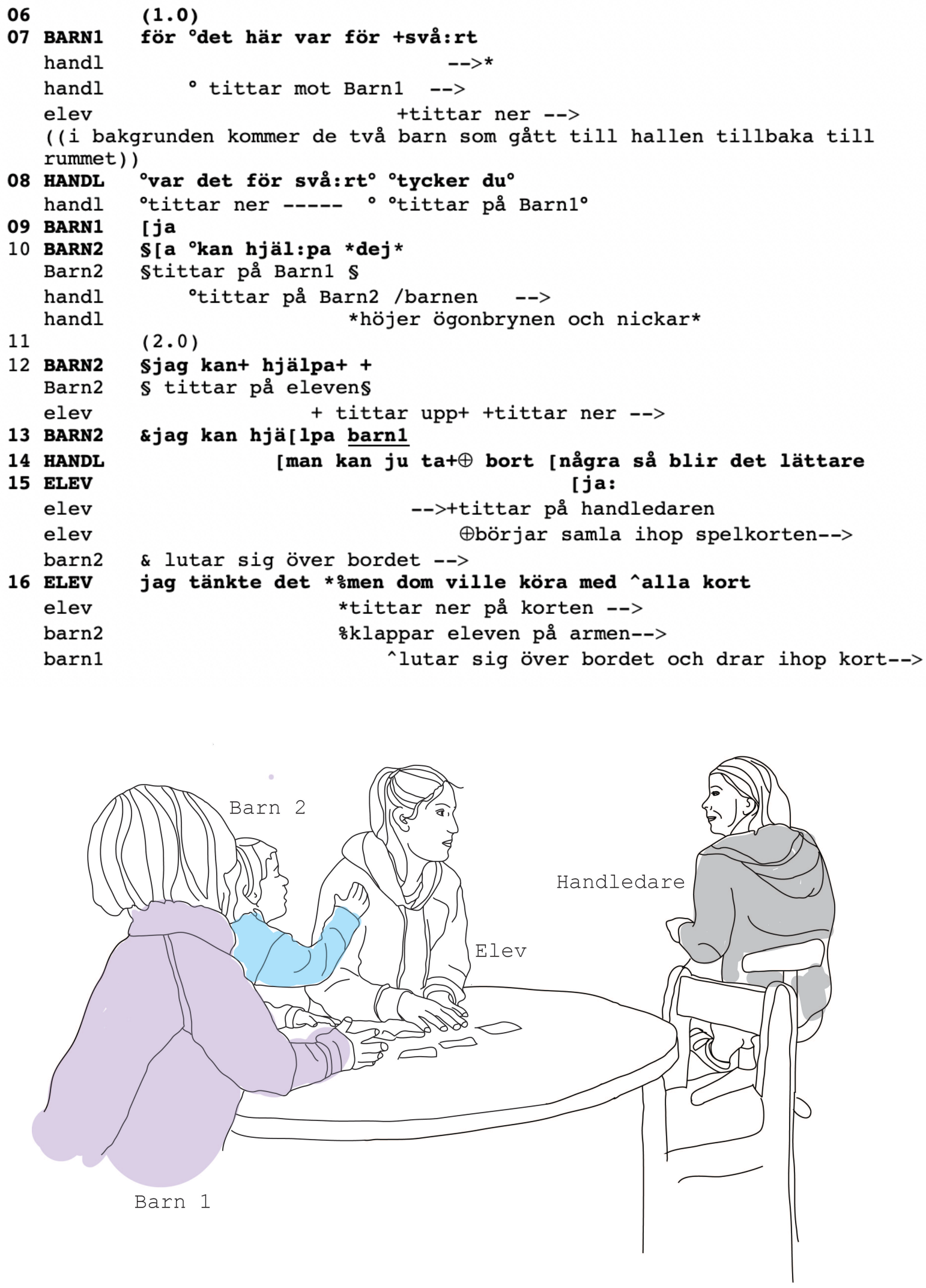
Ligga steget före: Barnskötares yrkesomdöme åskådliggjort genom bedömningshandlingar

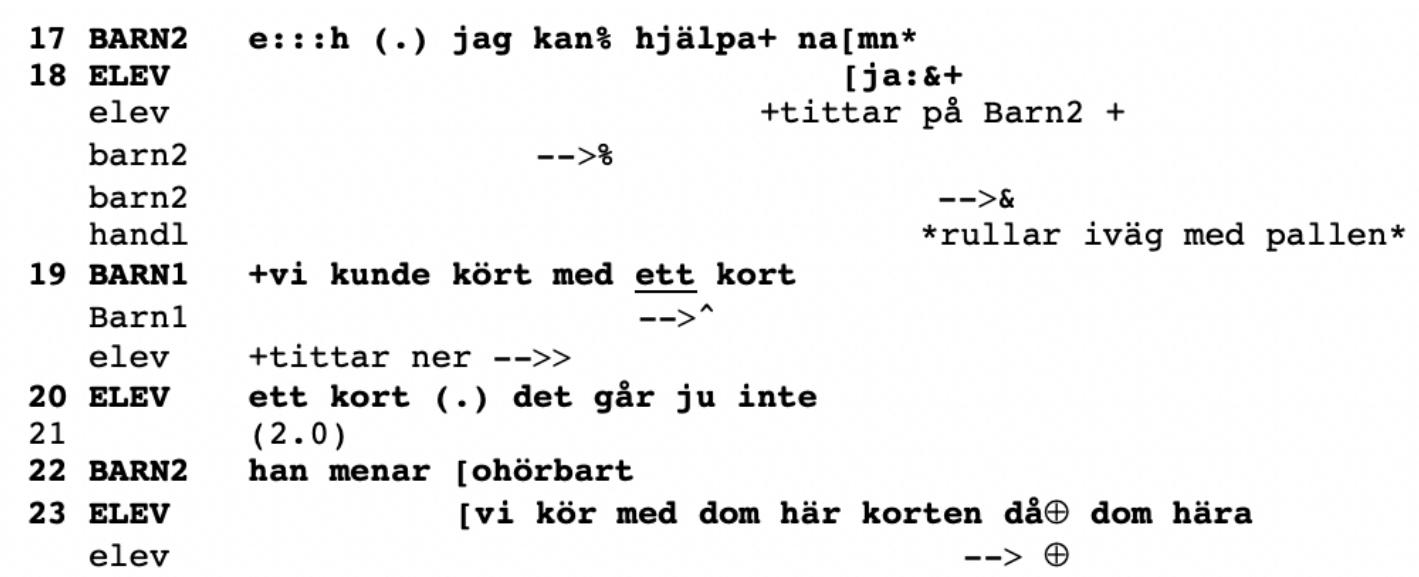

\section{Analys sekvens 1: Memory på Fiskmåsen - att främja deltagande}

Sekvensen ovan börjar med att handledaren vrider huvudet och riktar blicken mot gymnasieeleven under åtta (8) sekunder (rad 01). Denna inledande bedömningshandling (Goodwin \& Goodwin, 1992) åtföljs sedan av ytterligare kroppsliga och verbala handlingar. I pågående förskoleverksamhet - och i det sammantagna filmmaterialet - är att stanna upp och tyst iaktta i åtta sekunder att betrakta som en relativt lång tid. Under iakttagelsen tolkar handledaren, av allt att döma, situationen som utspelar sig vid bordet samt tar steget till att interagera. I bedömningshandlingarna och övriga handlingar som följer med detta steg, framträder barnskötarens yrkeskunnande inbegripet uttryck för yrkesomdöme. Genom gymnasieelevens samtidiga förhållningssätt och respons synliggörs skillnader visavi handledaren.

Handledaren rullar med pallen mot bordet samtidigt som hon ställer frågan "Har dom gett upp dom två andra eller?" (rad 02). Formuleringen "Har dom gett upp [vår kursivering] dom två andra?" kan förstås som att handledaren redan uppfattat att det är något i situationen som skaver. Gymnasieeleven svarar jakande på handledarens fråga ( rad 03) samtidigt som hon tittar på handledaren. Handledaren tittar mot hallen (rad 05), där de två barnen som gått ifrån bordet är (men inte syns i filmen). Genom att vrida sig mot hallen får handledaren överblick över hela situationen - inklusive de två "försvunna" barnen. Handledarens iakttagelse, tolkning och värdering av gymnasieelevens handlingar utgår därmed från en position som kan beskrivas som att handledaren har en överblick av situationen vid bordet, inklusive de två försvunna barnen (rad 05). Gymnasieeleven visar inga tecken på att inta denna slags vidvinkel och helhetssyn på situationen, utan förefaller helt fokuserad på aktiviteten "att spela". De två barnen som lämnat bordet förefaller därmed både bildligt och bokstavligt ha försvunnit ur gymnasieelevens synfält. I sekvensen framträder en annan relativt tydlig skillnad avseende expertens (handledarens) respektive novisens (gymnasieelevens) hantering av situationen. Att handledaren omedelbart uppfattar att spelet är för 
svårt för barnen uttrycks verbalt genom att benämna att de två frånvarande barnen "gett upp" (rad 03). Barn 1 tar del av samtalet och säger "jag kunde inte" (rad 04) följt av "för det här var för svårt" (rad 06). Handledaren bejakar genom sina verbala och kroppsliga handlingar Barn 1:s uttryck om att det är svårt - som besvaras (rad 07) genom att verbalt spegla uttryckssättet - respektive Barn 2:s uttryck om att vilja hjälpa, vilket i sig utgör exempel på samarbetande handling (Goodwin, 2018) respektive arbete för intersubjektivitet (Dalgren, 2017; Duranti \& Goodwin, 1992). Gymnasieeleven tittar ner mot bordet när Barn 2 säger sig kunna hjälpa Barn 1. Handledaren däremot riktar blicken mot Barn 2, nickar och höjer på ögonbrynen (rad 10) och bekräftar på detta sätt, kroppsligt inklusive med blick, barnets förslag; dock inte verbalt. Barn 2 tittar nu på gymnasieeleven och upprepar sitt förslag om att hjälpa Barn 1 (rad 12). Gymnasieeleven ger Barn 2 en snabb blick, men bekräftar inte på något avläsbart sätt förslaget. Parallellt framträder det däremot tydligt i handledarens interaktion med barnen - som framkommit - aktivt arbete med byggande av intersubjektivitet (Dalgren, 2017) genom samarbetande handlingar (Goodwin, 2018) med blickar, ansiktsuttryck och verbala utsagor.

Det sker en överlappande interaktion (rad 13-15) där Barn 2 lutar sig över bordet mot gymnasieeleven och återigen upprepar sitt förslag om att hjälpa Barn 1, samtidigt som handledaren föreslår att "man kan ta bort några [Memory-kort] så blir det lättare" (rad 14). Gymnasieeleven lyfter blicken mot handledaren och svarar jakande på förslaget, samt börjar samtidig samla ihop Memory-korten. Gymnasieeleven förklarar att "jag tänkte" (rad 16), med en motivering till varför barnen använder alla Memory-korten, "dom ville" (rad 16), samtidigt som hon åter tittar ner på bordet och fortsätter samla ihop Memory-korten. Barn 2 - som ännu inte fått respons från gymnasieeleven på sitt förslag att hjälpa Barn 1 - klappar nu gymnasieeleven upprepade gånger på armen för att påkalla uppmärksamhet (rad 16). Än en gång upprepar Barn 2 sitt verbala förslag samtidigt som hen fortsätter klappa gymnasieelevens arm (rad 17). Nu uppmärksammar gymnasieeleven Barn 2:s förslag med att titta på barnet och sedan verbalt svara jakande (rad 18). Barn 2 behöver alltså göra flera försök innan gymnasieeleven bejakar Barn 2 genom att tydligt verbalt och kroppsligt visa sig ha uppfattat viljan att hjälpa (rad 18).

Gymnasielevens verbala respons på handledarens förslag att minska antalet kort tyder på att även gymnasieeleven har uppfattat att det kommer att bli - och är - svårt att spela med alla Memorykort. Det framkommer dels genom att hon säger att hon tänkte ta färre kort, dels svarar jakande på handledarens fråga om huruvida de två försvunna barnen gett upp. Men gymnasieeleven, som inte har samma yrkeserfarenhet som barnskötaren och därmed inte har samma förutsättningar för yrkesomdöme, har trots att hon själv tänkte ta färre kort (i stället) valt att följa barnens önskemål om att spela Memory med alla kort. I gymnasieelevens förklaring framträder alltså en motsättning mellan barnens vilja att spela med 
alla kort och svårighetsgraden (för barn som är 3-5 år). Motsättningen kräver en avvägning mellan barnens önskningar, förutsättningar för spel samt förutsägelser - utifrån tidigare erfarenheter - om möjliga följder av de olika valen. Valet grundas också på tolkning av vad som är kärnan i spelaktiviteten. Det är just i denna typ av avvägningar, i situationer som karaktäriseras av motsättningar, som användning av yrkesomdöme blir synligt (jfr Göranzon, 2007; Lindberg 2003). I handledarens interaktion med barnen och eleven framträder en annan uttolkning av kärnan för aktiviteten: att det handlar om att främja ett lyckat deltagande för barnen. Handledarens bedömningshandlingar (Goodwin \& Goodwin, 1992) innefattar verbala anvisningar som gör det enkelt för gymnasieeleven att omforma spelet - så att barnens delaktighet främjas. Handledaren rullar bort på sin rullpall och spelet återupptas med färre kort, när gymnasieeleven bekräftat sin förståelse av det som förmedlats.

Sammanfattningsvis visar sekvensen hur handledarens erfarenhet gör att hon urskiljer och erfar situationen på ett annat sätt än gymnasieeleven - att aktiviteten för en barnskötare handlar om att främja deltagande snarare än "att spela", och att det är i relation till detta vad som omdömet - valen att agera - synliggörs. Bedömningshandlingarna visar att yrkeskunnande-i-handling i denna situation innebär att kunna ändra förutsättningar som en följd av barnens handlingar, att främja deltagande (Goodwin, 2018) och bygga intersubjektivitet (Dalgren, 2017; Duranti \& Goodwin, 1992) med barnen både individuellt och som grupp.

\section{Daggmasken: Mumsig lera och vikten av att fånga uppmärksamheten}

Den andra sekvensen utspelar sig på en annan förskola. Det är eftermiddag och aktiviteterna har återupptagits efter att barnen har vilat. Vid ett bord håller fem barn på att leka med leklera i olika färger, tillsammans med en handledare och en gymnasieelev. På bordet finns, utöver leran, olika redskap i en låda. Handledaren samspelar med barnen genom att upprepa det som sägs, titta på barnen och samtala. Hon har även initierat en gemensam sång- och räknelek med lerfigurer, om en krokodil och fem små apor i ett träd, apor som krokodilen äter upp en i taget. Barnen deltar entusiastiskt i sjungandet och räknandet av hur många apor det blir kvar när krokodilen äter upp aporna, en efter en. Även gymnasieeleven sjunger med, men har inte varit direkt aktiv i övrigt. När sången är slut vill barnen sjunga ramsan en gång till, men denna gång med en apa som äter upp små krokodiler. Handledaren uppmanar barnen att börja göra krokodiler av leran. Den transkriberade sekvensen1 börjar strax därefter, när handledaren börjar rikta om sin uppmärksamhet mot ett barn som äter av lekleran. 
Enni Paul \& Camilla Gåfvels

Sekvens 2: Leklera på Daggmasken

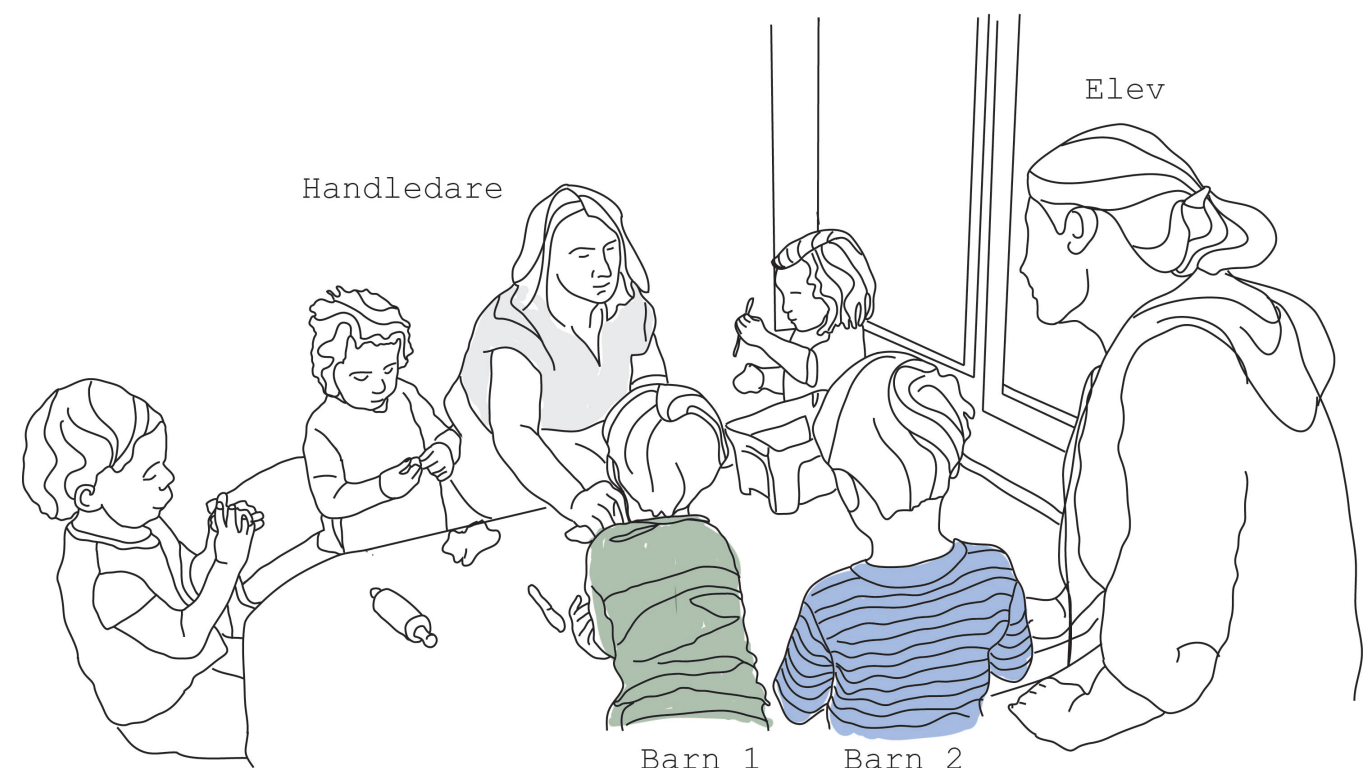

01 HANDL ${ }^{\circ}$ Nu får ni göra krokodilerna ${ }^{\circ}$ nu då

$-->^{0}$ handl ' tittar på barnen mittemot ${ }^{\circ}$ tittar ner på sina knådande händer ${ }^{\circ}$ elev $\oplus$ knådar en bit lera -->

elev + tittar på sina händer -->

02 HANDL ${ }^{\circ}$ kanske Emilia kan ${ }^{\circ}$ hjälpa er göra krokodilerna $i$ trädet istället

handl • tittar på eleven ${ }^{\circ}$ tittar åt sidan på barn 3 -->

$03(4.0)$

04 handl *drar fram en pall bredvid sig

handl ${ }^{\circ} k a s t a r$ en blick på eleven

05 BARN1 kan du göra en \$ sån här stor apa barn1

$\$$ lägger sig över bordet och rullar en stor lerklump mot handl

06 BARN1 'kan du *göra en \$sån [stor apa* barn1 \$ släpper lerklumpen och drar bort sin hand handl ${ }^{\circ}$ tittar på barn $1-\rightarrow$ handl

*lägger sin hand på lerklumpen*

07 HANDL [*Emilia ${ }^{\circ} \mathrm{hjälper} \mathrm{dig} \mathrm{**där} \mathrm{med} \mathrm{krokodi} \oplus$ lerna och apan

handl

handl

$->$ 'tittar på barn 3 -->

handl

* lyfter lerklumpen lägger mitt på bordet*

elev

* tar upp något från golvet -->

$-\rightarrow \oplus \oplus$ sträcker sin arm och tar lerklumpen

08 ELEV $+\oplus \mathrm{Mm}$ : fem stycken krokodiler $\circ \circ$

elev + tittar på leran -->

elev $\oplus$ bryter av en bit lera $->$

handl

-->otittar runt på barnen' tittar på elevo tittar på Barn2--> 
Ligga steget före: Barnskötares yrkesomdöme åskådliggjort genom bedömningshandlingar
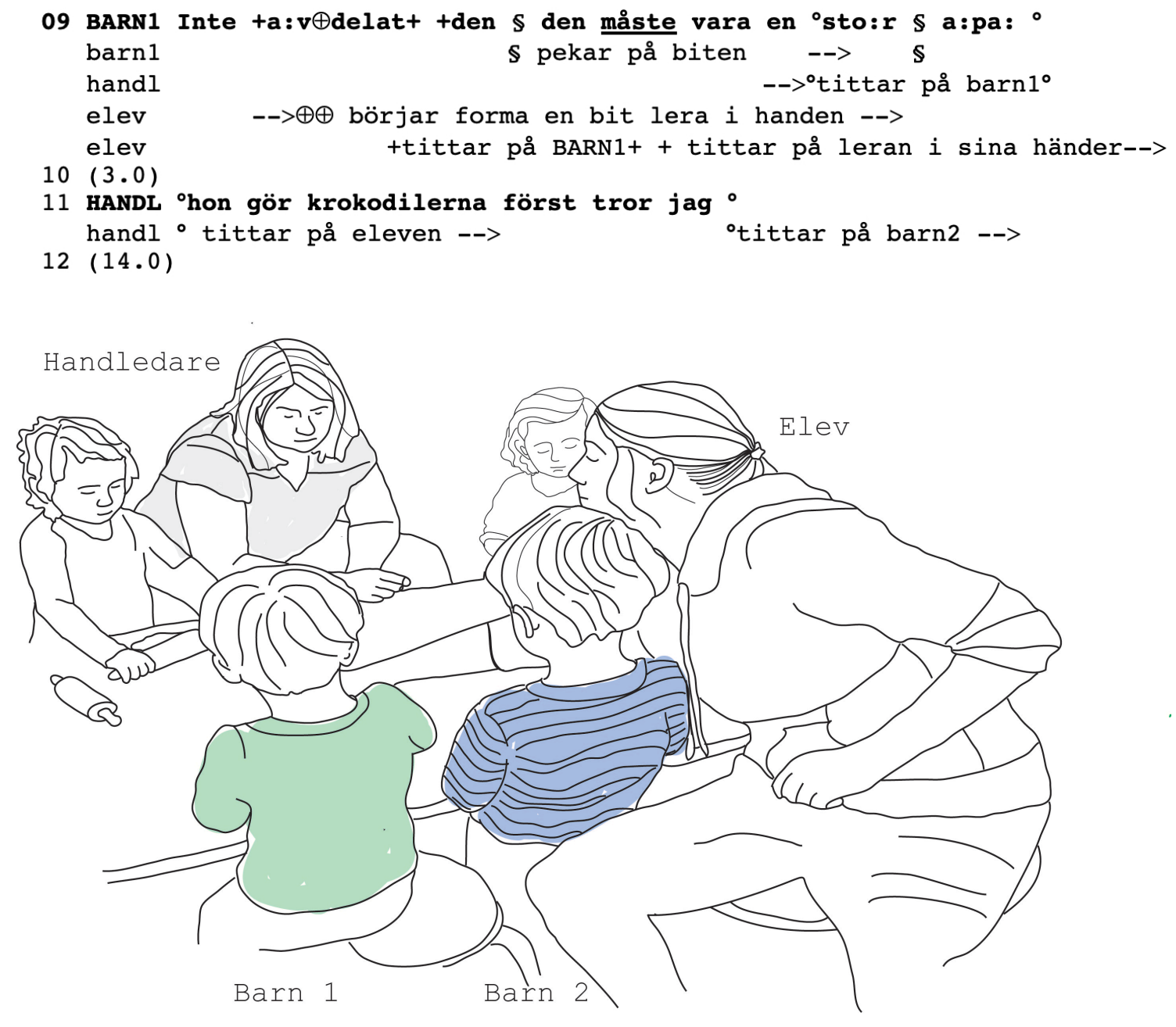

13 ELEV jag behöver+ +en kn ${ }^{\circ} \mathbf{i}$ v+ då $\oplus-->\oplus$

elev $\quad->+$ +tittar på låda med redskap + tittar mot mitten av bordet

$\oplus$ sträcker sig mot en kniv $\oplus$

- tittar på elev • tittar på elevens hand

14 elev $\oplus$ tar kniven och börjar forma lerbiten -->

elev + tittar på lerbiten -->

15 handl ${ }^{\circ}$ tittar på elev --> (11.0)

16 barn1 \$ sträcker plastkniv mot eleven -->

$17(2.0)$

18 ELEV jag har en kniv $\$ \$$

barn1 - $>\$$ drar tillbaka sin arm med kniven\$

19 HANDL Det får inte ta för lång tid Emilia

20 HANDL $\oplus$ §för då kommer du tappa barnen $\oplus$ snart

elev --> lägger första lerkrokodilen på bordet $\oplus$

barn1 \$ skär i stora lerklumpen med plastkniven --> 


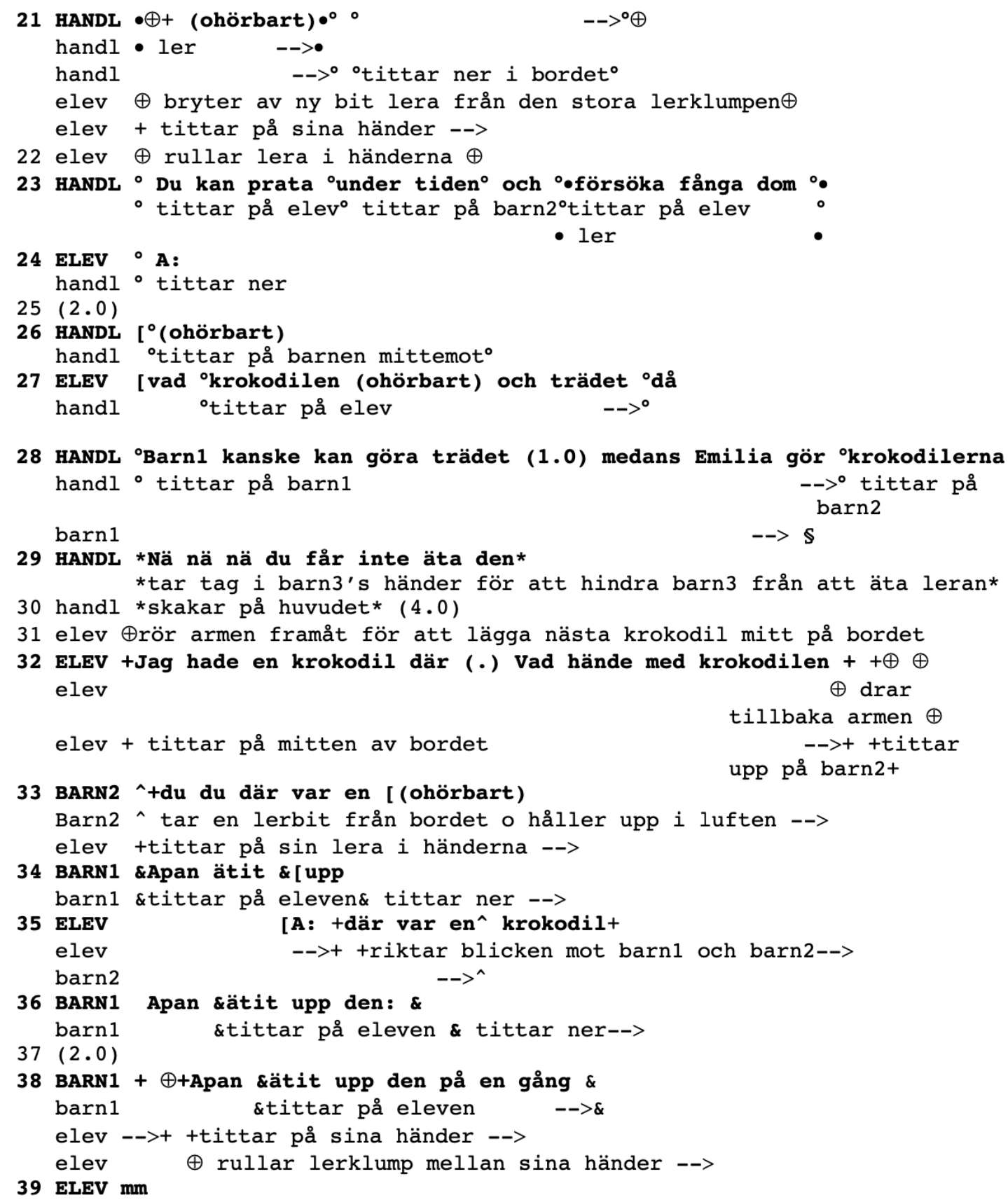

Analys sekvens 2: Leklera på Daggmasken - interagera och hjälpa göra krokodiler Utdraget ovan börjar med att handledaren, som sitter i mitten av barngruppen, initierar ett görande av lerkrokodiler. Barnen har knappt påbörjat arbetet med krokodilerna när handledaren säger att "kanske Emilia [gymnasieeleven] kan hjälpa er göra krokodilerna i trädet i stället" (rad 02) och som en del av bedömningshandlingen (Goodwin \& Goodwin, 1992) riktar blicken mot gymnasieeleven, som sitter lite vid sidan av. Gymnasieeleven arbetar koncentrerat med en 
lerklump. Denna relativa sociala passivitet gentemot barnen är något som handledaren tycks uppmärksamma, vilket framträder i sekvensen genom handledarens återkommande blickar på gymnasieeleven ( $\mathrm{rad} 02,08,16-21,23,27)$. Mot denna bakgrund bjuder handledaren snart åter aktivt in gymnasieeleven i den gemensamma aktiviteten (jfr Goodwin, 2018), då Barn 1 påkallar uppmärksamhet genom att hålla fram en lerklump och böja sig fram över bordet mot handledaren och säga "kan du göra en sån här apa" (rad 05-06). Till svar får barnet att gymnasieeleven kan hjälpa till att göra krokodilerna och apan: "Emilia hjälper dig med krokodilerna och apan" (rad 07). Gymnasieeleven svarar på uppmaningen genom att säga "mm fem stycken krokodiler" (rad 08), med blicken fortsatt riktad mot leran.

Efter en kort stund säger gymnasieeleven att hon "behöver en kniv" (rad 13), sträcker sig efter och tar en från bordet. Barn 1 hör gymnasieeleven och försöker överräcka en plastkniv ( rad 16-18) - en handling som gymnasieeleven först inte fångar upp då hon åter arbetar koncentrerat med leran. Först efter att Barn 1 hållit fram kniven under tystnad i två sekunder säger gymnasieeleven att hon redan "har en kniv" (rad 18). Handledarens bedömningshandling (Goodwin \& Goodwin, 1992) fortsätter genom att hon under tiden tittar tyst på gymnasieeleven i 11 sekunder (rad 15-22) och sedan säger "Det får inte ta för lång tid Emilia för då kommer du tappa barnen snart" (rad 19-20) följt av "Du kan prata under tiden och försöka fånga dom" (rad 23). Gymnasieeleven besvarar handledarens uppmaning med ett " $\mathrm{Aa}$ " ( $\mathrm{rad} 24)$ och ställer sedan efter en kort tystnad några frågor till barnen (rad 27, rad 32) parallellt med fortsatt arbete med leran. Gymnasieeleven tittar även upp något mer på barnen ( $\operatorname{rad} 32,35)$, efter handledarens uppmaning.

Handledarens bedömningshandlingar (Goodwin \& Goodwin, 1992) - i första hand den värderande blicken och de verbala uppmaningarna - synliggör att gymnasieelevens inledande handlingar inte överensstämmer med handledarens intentioner. Handledaren har försökt få barnen att göra lerfigurerna till ramsan (rad 1) och anger två gånger att gymnasieeleven kan hjälpa barnen att göra figurerna - varmed det från handledarens perspektiv aldrig har handlat om att göra figurerna åt barnen. Dessutom säger handledaren att Barn 1 kan göra trädet när gymnasieeleven gör krokodilerna (rad 28). Därutöver följer, som nämnts, ett flertal bedömningshandlingar och verbala uppmaningar till gymnasieeleven om att inte tappa barnen respektive explicit verbal handledning om hur gymnasieeleven kan och bör göra, exempelvis "Du kan prata under tiden och försöka fånga dom." $(\operatorname{rad} 23)$.

Senare börjar ett barn äta av leran (rad 29), handledaren ingriper och gymnasieeleven upptäcker i samma veva att en lerkrokodil på något sätt har försvunnit från bordet. Ungefär samtidigt som handledaren hindrar Barn 3 från att äta lera, frågar gymnasieeleven barnen var krokodilen tagit vägen och får till svar att "Apan ätit upp den" (rad 34). Barn 1 säger samma sak en gång till och får svar 
från gymnasieeleven att "Aa där var en krokodil" (rad 35), senare ett "Mm" (rad 39) och en snabb blick. Gymnasieelevens interaktion riktad direkt mot barnen kommer i gång mot slutet av den transkriberade sekvensen, av allt att döma som ett resultat av handledarens bedömningshandlingar. Efter det transkriberade avsnittet fokuserar handledaren på Barn 3, för att hindra barnet från att äta ännu mer lera. Handledaren går strax därefter i väg med det ifrågavarande barnet för att dricka vatten. Gymnasieeleven fortsätter göra krokodiler av leran. Senare sjunger gymnasieeleven och de två barn som är kvar ramsan.

Vid en tillbakablick mot den transkriberade sekvensens inledning förefaller gymnasieeleven helt enkelt ha fastnat i (eget) görande av krokodiler och därför inte förmå att fullt ut ta steget till samarbetande handlingar (Goodwin, 2018) och arbete för intersubjektivitet (Dalgren, 2017; Duranti \& Goodwin, 1992). I relation till de förmågor som handledaren uppvisar under interaktionen framstår det som att det eftersträvade yrkeskunnandet innefattar att i nuet skapa mening tillsammans med barnen, individuellt och som grupp. För detta krävs yrkesomdöme att uppfatta vad kärnan i aktiviteten är - och anpassningsförmåga som innefattar att kunna kommunicera med barnen kroppsligt och verbalt, samt att kunna tolka och agera på vad barnen intresserar sig för i relation till syftet med aktiviteten så som den tar form i den flytande situationen - $\mathrm{i}$ "nuet".

Sammanfattningsvis visar även denna sekvens en skillnad i hur gymnasieelev och handledare uppfattar situationen och tolkar meningen med aktiviteten - att göra lerfigurer eller att engagera barnen - vilket också påverkar hur de väljer att handla. Bedömningshandlingarna (Goodwin \& Goodwin, 1992) visar att yrkeskunnande-i-handling i denna situation innebär att kunna aktivera barnen i ett görande, samt att fånga och bibehålla barnens intresse genom att bygga intersubjektivitet (Dalgren, 2017) tillsammans med barnen.

\section{Fiskmåsen och Daggmasken: Intersubjektivitet i fokus för handledare}

Något som blir framträdande då båda sekvenserna ställs jämte varandra är hur gymnasieelevernas uppmärksamhet av allt att döma främst är riktad mot det fysiska arbetsmaterialet - i det första fallet Memorykort och i det andra fallet leklera - snarare än mot barnens upplevelser uttryckta genom deras handlingar. Denna uppmärksamhetsinriktning kan tas som inteckning för hur gymnasieeleverna jämfört med handledarna - inledningsvis har ett fokus som framstår som mindre intersubjektivt och mer instrumentellt; $i$ det senare fallet $i$ betydelsen att uppmärksamheten riktas mot ting snarare än personer. Åtminstone i början av sekvenserna verkar aktiviteterna för gymnasieelevernas del avgjort handla om att "spela Memory" respektive "göra lerfigurer", med fokus på det materiella görandet. De mer erfarna (barnskötarna tillika handledarna) väljer i första hand alltid att interagera med barnen på ett följsamt sätt, där följsamheten kännetecknas av samarbetande handlingar (Goodwin, 2018) för byggande av intersubjektivitet (Dalgren, 2017). I denna process använder handledarna förkroppsligad 
urskiljningsförmåga i form av omdöme för löpande justeringar i relation till både individers och gruppens handlingar utifrån en tolkning av vad som utgör kärnan i pågående aktivitet.

I båda sekvenserna framstår det också som att en påtaglig skillnad gentemot handledare är att gymnasieeleverna inte har en lika omfattande överblick och helhetssyn som de förra. I den första sekvensen, Memory på Fiskmåsen, blir det tydligt i förhållande till de två barn som valt att lämna spelet. I den andra sekvensen, Leklera på Daggmasken, blir det i första hand urskiljbart i förhållande till vad som motiverar barnens aktiva deltagande. Eller annorlunda uttryckt, vad som kan upprätthålla deras intresse och engagemang för den pågående aktiviteten; varmed frånvaron av detta därmed även kan sägas vara vad som föranleder att två barn "försvinner" från Memory på Fiskmåsen eller att eleven riskerar att "tappa barnen" i Leklera på Daggmasken. Detta kan - utifrån en jämförelse med ett annat sammanhang - liknas vid hur Tsagalidis (2008) visar att yrkeslärare anger att elever i början av sin utbildning saknar helhetstänkande, vilket blir ett hinder för praktiskt klokt handlande. Det senare innebär (i en överförd betydelse oavsett vad för slags verksamhet det rör sig om) att till exempel kunna förstå hur olika delar i verksamheten eller den pågående arbetsprocessen hänger ihop samt att urskilja vad det väsentliga är för verksamheten i det som sker i en situation; i stället för att fokusera på i det större sammanhanget (relativt obetydliga) enskilda och konkreta detaljer. I sekvenserna från Fiskmåsen respektive Daggmasken visar gymnasieelevernas handlingar fokus på vad som i det större sammanhanget framstår som enskilda detaljer. Gymnasieeleverna har alltså sannolikt ännu inte utvecklat ett helhetstänk eller uppfattat vad kärnan är i aktiviteterna som genomförs med barnen. Det bör därför också samtidigt framhållas att detta är förklarligt givet gymnasieelevernas begränsade yrkeserfarenhet, samt att de genom att se, delta och agera - och genom handledning i pågående situationer som i ovan skildrade exempel - bereds möjlighet att utveckla förmåga att urskilja och erfara fler nyanser (jfr Carlgren, 2015). Idealt sker därmed med tiden en gradvis rörelse mot ett mer nyanserat sätt att se, agera och vara i den aktuella praktiken, där handledarens bedömningshandlingar utgör komponenter som bidrar till att gymnasieeleverna - så småningom - kan förstå och handla på ett sätt som överensstämmer med det yrkesomdöme som handledarna uppvisar i de båda återgivna sekvenserna.

I båda sekvenserna förmedlar handledarnas bedömningshandlingar att gymnasieelevernas (begränsade) samspel med barnen har eller kan komma att leda till att förskolebarnen tröttnar på aktiviteten, vilket är direkt utläsbart i de verbala formuleringarna "har dom gett upp", i sekvens 1, respektive "du kommer tappa barnen" i sekvens 2. Det går därmed även att anta att handledarna skulle ha valt att handla på annat sätt än gymnasieeleverna. Dessa skillnader i vad gymnasieeleverna gör och vad det framstår som att handledarna sannolikt skulle välja att göra, blir urskiljbara när handledarnas bedömningshandlingar vägleder 
gymnasieeleverna till att försöka handla på ett annat sätt. Dessa situationer synliggör därmed även skillnader i yrkesomdöme. Därigenom finns nu - efter det senaste analyssteget som stöder sig på båda sekvenserna - underlag för att ge ett sammanfattande svar på studiens frågeställning, om vilket yrkesomdöme som blir urskiljbart genom handledares bedömningshandlingar. Svaret som framträder genom de granskade bedömningshandlingarna pekar mot att yrkesomdöme behöver aktiveras dels för att avgöra vad som är meningen med en pågående aktivitet, dels - i relation till föregående - för att avgöra hur en därför ska välja att handla. Yrkesomdömet möjliggör sedan för barnskötare att samtidigt agera konstruktivt på två fronter, som kan beskrivas som en mikro- respektive makronivå för den enskilda barngruppen:

- Att i pågående situationer skapa mening tillsammans med barnen, vilket innefattar att kroppsligt och verbalt kommunicera med barnen - som grupp respektive som individer - samt att kunna tolka vad barnen är intresserade av/har behov av/möter i det pågående skeendet, och därigenom även förstå och leda barnen dit de är på väg.

- Att ha en förkroppsligad överblick av helhetssituationen samtidigt med full översikt över grupp såväl som ingående enskilda barn för att använda detta som grund för att fatta beslut för handling i situationen.

Som metafor för vad de två punkterna ovan innebär kan anges att den ena punkten innebär närhet till barnen i ett "nu" och den andra kräver viss distans. Det rör sig därmed om att aktivera yrkesomdömet för att för det första avläsa och agera i situationen "i nuet", och för det andra "ligga steget före" genom att löpande tolka möjliga konsekvenser av olika val i den vardagliga interaktionen.

\section{Diskussion: Att kunna handla omdömesgillt}

Denna artikel har undersökt barnskötares yrkesomdöme - genom att studera handledares bedömningshandlingar riktade mot gymnasielever under arbetsplatsförlagt lärande - i samspel med förskolebarn. Vad experterna (i form av erfarna barnskötare) kan, har framkommit i relation till vad noviserna (i form av mindre erfarna gymnasieelever) ännu inte kan. Bornemark (2020) framhåller det situationsunika i relation till behovet av yrkesomdöme i mellanmänskliga yrken, vilket innebär att yrkesomdömet behöver aktiveras i en pågående situation både i relation till barnens handlingar och tolkning av förskolans uppdrag. Inramningen av förskoleverksamheten kan i förhållande till barnet vara mer eller mindre intersubjektiv respektive mer eller mindre instrumentell. För att gymnasieelever ska tillägna sig kunnande i arbete för att främja intersubjektivitet behöver de möta situationer där det blir möjligt att urskilja och erfara sinnligt (jfr Göranzon, 2007). Därmed utgör arbetsplatsförlagt lärande och handledarens 
bedömningshandlingar en viktig komponent för att peka på andra möjliga sätt att handla, än de sätt att agera som eleverna initialt valt i de två transkriberade sekvenserna. Gymnasieeleverna kan succesivt tillägna sig yrkesomdöme genom att få möjlighet att bygga upp en repertoar av alternativa sätt att handla i liknande situationer, vad som framstår som praktiskt kloka val i relation till verksamhetens kärna. Det innebär att gymnasieeleverna så småningom skulle kunna välja att fokusera mer på samarbetande handlingar och arbete för att främja intersubjektivitet - tillsammans med barnen - än på det instrumentella görandet med ting.

Även Pröckl (2020) betonar det situerade och intersubjektiviteten, vilka benämns som den mellankroppsliga sfären. Aktuella förmågor innefattar att kunna "lyssna framåt och mitt i allt som händer i vardagen vara i samspel med sin barngrupp på ett musiskt sätt, så att det uppstår sväng i stället för osynk och dialog i stället för tjat" (s. 219). I relation till den ovan redovisade resultatframställningen verkar detta ligga väldigt nära vad som denna studie beskrivit med metaforen att "ligga steget före" i ett "nu". Detta indikerar i sin tur att i termer av barnskötares yrkesomdöme utgör intersubjektiviteten själva grundstenen; en praktisk kunskap som är avgörande för omdömesgilla handlingar under föränderliga förhållanden. Yrkesomdöme aktiveras i situationer där barnskötare behöver kunna tolka och förstå meningen med en aktivitet, se och handla i relation till det unika i varje situation (Bornemark, 2020) samt kunna göra förutsägelser om barnens möjliga reaktioner i relation till olika val, så som framkommer i de två empiriska exemplen i denna artikel. Det skadar inte att återigen upprepa att barnskötare behöver göra val i relation till en icke reducerbar osäkerhet (Göranzon, 2007). Denna osäkerhet hanteras på olika sätt av gymnasieelever respektive handledare i studiens empiriska material, utifrån deras respektive förutvarande (skilda) erfarenheter. Genom handledarnas bedömningshandlingar blir det möjligt för eleverna att se sina egna val i relation till handledarnas. Att utveckla ett omdömesgillt handlande är på detta sätt sammanvävt med att upptäcka möjligheter som uppstår i varje unik situation. Handledares bedömningshandlingar möjliggör därmed tillfällen för utveckling.

Såsom antytts i inledningen av denna artikel finns risk att barnskötaryrkets otydliga definition, samt hur utbildningen kommit att efterlikna en reducerad version av förskollärarutbildningen, leder till att barnskötarnas specifika yrkeskunnande osynliggörs (Plymoth \& Reimers, 2015). Att förkroppsligade handlingar och praktiskt kunnande inom förskolemiljön länge förblivit outforskade (Pröckl, 2020), sammanhänger sannolikt med professionaliseringstendensen, men också med att yrkeskunnandets relativt tysta (Polanyi, 1967/2009) dimensioner - såsom just omdöme - av förklarliga skäl inte går att ta på, mäta och enkelt utvärdera. Då den yrkeskunniges omdöme inte aktiveras på ett medvetet plan varje gång, utan är intuitivt och förkroppsligat (Göranzon, 2007), innebär det återigen att det kan vara svårt att som yrkeskunnig verbalt uttrycka vad som 
utgör tecken på yrkesomdöme - oavsett yrkesroll. Yrkesroller som betraktats som underordnande har det sannolikt ännu svårare, vilket kan tänkas gälla för barnskötare i förskolemiljön. Allt detta har även konsekvenser för gymnasial yrkesutbildning. Som nämndes i inledningen fokuserar den gymnasiala yrkesutbildningen i hög grad på formulerad kunskap (Carlgren, 2015), vilket gör att ett sådant område som omdöme blir svårt att hantera. Inom Barn- och fritidsprogrammet är det dessutom andra yrkesgruppers - än barnskötares - utbildningar och kunskapsinnehåll som utgör måttstock (jfr Plymoth \& Reimers, 2015). Det innebär i förlängningen att det kunnande som skolan lägger tonvikten på att utveckla och bedöma, inte är detsamma som det kunnande som betonas på arbetsplatser och som gymnasieelever där får möjlighet att tillägna sig (jfr Carlgren, 2015). Detta knyter också an till Mårtenssons (2014) konstaterande att mycket av handledningen i förskolan sker "i farten" i den pågående verksamheten med barnen, samt därmed förefaller såväl osynlig som avgjort tyst med åtföljande risk att förbigås i formella utbildningssammanhang. Som denna artikel visar framträder barnskötares yrkeskunnande vid multimodal interaktionsanalys av den vardagliga förskoleverksamheten. För att yrkeskunnande som kommer till uttryck i handling - så som yrkesomdöme - ska få en mer framträdande roll i elevernas yrkesutbildning, finns två möjliga vägar att gå. Det första alternativet är att försöka beskriva och lyfta fram yrkeskunnandet. Det andra alternativet är att - på mer teoretiska grunder - försöka stärka ställningen för de tysta dimensionerna av yrkeskunnande. Föreliggande artikel har försökt göra både och.

\section{Slutnot}

${ }^{1}$ De verbala och fysiska handlingar som genomförs av barn som inte interagerar med gymnasieeleven har inte transkriberats. Det innebär att det som de två barnen längst till vänster (i bild 3) gör inte har transkriberats.

\section{Om författarna}

Enni Paul arbetar som lektor vid Specialpedagogiska institutionen och som postdoktor vid Institutionen för språkdidaktik vid Stockholms universitet. Hennes forskningsintressen kretsar kring skriftbruk i yrkesutbildning, yrkesdidaktik samt möjligheter att lära i olika miljöer.

Camilla Gåfvels är lektor vid Institutionen för bild- och slöjdpedagogik på Konstfack, Stockholm, med forskningsintressen centrerade kring yrkeskunnande respektive områden kopplade till bedömning, i skola såväl som arbetsliv. Hon bedriver även undervisningsutvecklande forskning i praktiskt estetiska ämnen. 
Ligga steget före: Barnskötares yrkesomdöme åskådliggjort genom bedömningshandlingar

\section{Referenser}

Bateman, A. \& Church, A. (2017). Children's knowledge-in-interaction: An introduction. I A. Bateman \& A. Church (Red.), Children's knowledge-in-interaction: Studies in conversation analysis (s. 1-11). Springer.

Bornemark, J. (2020). Horisonten finns alltid kvar: Om det bortglömda omdömet. Volante.

Broth, M. \& Keevallik, L. (2020). Multimodal interaktionsanalys. Studentlitteratur.

Carlgren, I. (2015). Kunskapskulturer och undervisningspraktiker. Daidalos.

Carlgren, I. \& Nyberg, G. (2015). Från ord till rörelser och dans: En analys av rörelsekunnande i en dansuppgift. Forskning om undervisning och lärande, 14, 24-40.

Chan, S. (2015). Apprentices' learning of occupationally informed practical judgment. Vocations and Learning, 8, 335-351. https:/ / doi.org/10.1007/s12186-0159134-3

Cromdal, J. \& Dalgren, S. (2020). Samspel i förskolans vardag. I M. Broth \& L. Keevallik (Red.), Multimodal interaktionsanalys (s. 287-302). Studentlitteratur.

Dalgren, S. (2017). Att göra pedagogisk praktik tillsammans: Socialt samspel iförskolans vardag. [Doktorsavhandling, Linköpings universitet].

Filliettaz, L. (2010). Guidance as an interactional accomplishment practice-based learning within the Swiss VET system. I. S. Billett (Red.), Learning through practice: Models, traditions, orientations and approaches (s. 156-179). Springer. https:/ / doi.org/10.1007/978-90-481-3939-2_9

Goodwin, C. (1997). The blackness of black: Color categories as situated practice. I L. B. Resnick, R. Säljö, C. Pontecorvo \& B. Burge (Red.), Discourse, tools and reasoning: Essays on situated cognition (s. 111-140). Springer.

Goodwin, C. (2018). Co-operative action. Cambridge University Press.

Goodwin, C. \& Goodwin, M. H. (1992). Assessments and the construction of context. I A. Duranti \& C. Goodwin (Red.), Rethinking context: Language as an interactive phenomenon (s.147-190). Cambridge University Press.

Goodwin, C. \& Duranti, D. (1992). Rethinking context: An introduction. I. A. Duranti \& C. Goodwin (Red.), Rethinking context: Language as an interactive phenomenon (s. 1-42). Cambridge University Press.

Goodwin, M. \& Kyratzis, A. (2011). Peer language socialization. I A. Duranti, E. Ochs \& B. Schieffelin (Red.), The handbook of language socialization (s. 365-390). Wiley.

Gåfvels, C. (2016). Skolad blick på blommor: Formandet av yrkeskunnande i floristutbildning [Doktorsavhandling, Institutionen för pedagogik och didaktik, Stockholms universitet].

Gåfvels, C. \& Paul, E. (2020). Tre fallstudier av yrkeskunnande inom gymnasieskolans lärlingsutbildning. Skolverket.

Göranzon, B. (2007). Bildning och teknologi (Rapport 2007:57). Högskoleverket. 
Insulander, E., Majlesi, A. R., Rydell, M. \& Åberg, E. S. (2021). Multimodal analys av klassrumsinteraktion. Liber.

Janik, A. (1991). Cordelias tystnad: Om reflektionens kunskapsteori. Carlsson.

Jonsson, A. (2013). Att skapa läroplan för de yngsta barnen i förskolan: Barns perspektiv och nuets didaktik [Doktorsavhandling, Göteborgs Universitet].

Jonsson, A., Williams, P. \& Samuelsson, I. (2017). Undervisningsbegreppet och dess innebörder uttryckta av förskolans lärare. Forskning om undervisning och lärande, 5(1), 90-109.

Lindberg, V. (2003). Yrkesutbildning i omvandling: En studie av lärandepraktiker och kunskapstransformationer. [Doktorsavhandling, Stockholms universitet].

Lindberg, V., Fejes, A. \& Wärvik, G.-B. (2017). Introduktion. I. A. Fejes, V. Lindberg \& G.-B. Wärvik (Red.), Yrkesdidaktikens mångfald (s. 15-21). Lärarförlaget.

Majlesi, A. R., Jansson, G. \& Rydell, M. (2020). Gester. I. M. Broth \& L. Keevallik (Red.), Multimodal interaktionsanalys (s. 123-141). Studentlitteratur.

Molander, B. (1996). Kunskap i handling. Daidalos.

Mondada, L. (2016). Conventions for multimodal transcription. https://franzoesistik.philhist.unibas.ch/fileadmin/user_upload/franzoesistik/mondada_multimodal_conventions.pdf

Mårtensson, A. (2014). Handledare och handledning: Gymnasial yrkesutbildning på förskola. [Licentiatuppsats, Linköpings universitet].

Nilsson, C. (2009). Fronesis och den mänskliga tillvaron: En läsning av bok VI i Aristoteles Nikomachiska etik. I. J. Bornemark \& F. Svenaeus (Red.), Vad är praktisk kunskap (s. 39-54). Södertörns högskola.

Olsson, M., Lindgren Eneflo, E. \& Lindqvist, G. (2020). Undervisning i förskolan: En företeelse i rörelse. Pedagogisk forskning i Sverige, 25(4), 30-56. https:/ / doi.org/10.15626/pfs25.04.02

Panican, A. \& Paul, E. (2019). Svensk gymnasial yrkesutbildning: En framgångsfaktor för en effektiv övergång från skola till arbetsliv eller kejsarens nya kläder? Svenska ESF-rådet.

Paul, E. \& Gåfvels, C. (2020). Lärling eller skolutbildning: Olika vägar mot samma mål? Skolverket.

Plymoth, B. \& Reimers, E. (2015). A historical overview: Care and education intersecting with status and class in Swedish childminder education 1975-2011. Tidsskrift for Nordisk barnehageforskning, 9(3), 1-16. https:/ / doi.org/10.7577/nbf.641

Polanyi, M. (1967/2009). The tacit dimension. University of Chicago Press.

Pröckl, M. (2020). Tyngd, sväng och empatisk timing: Förskollärares kroppsliga kunskaper. [Doktorsavhandling, Södertörns högskola].

SFS 2010:800. Skollag. https://www.riksdagen.se/sv/dokument-lagar/dokument/svensk-forfattningssamling/skollag-2010800_sfs-2010-800

Skolverket. (2011). Läroplan, examensmål och gymnasiegemensamma ämnen för gymnasieskola 2011. 
Skolverket. (2018). Läroplan för förskolan, Lpfö 18.

Skolverket. (2019). Barn och personal i förskola 2019: Beskrivande statistik (Dnr 2020:230).

Streeck, J., Goodwin, C. \& LeBaron, C. (2011). Embodied interaction: Language and body in the material world. Cambridge University Press.

Tsagalidis, H. (2008). Därför fick jag bara Godkänt: Bedömning i karaktärsämnen på HR-programmet. [Doktorsavhandling, Stockholms universitet].

Tyson, R. (2017). The rough ground: Narrative explorations of vocational Bildung and wisdom in practice. [Doktorsavhandling, Stockholms universitet].

Vetenskapsrådet. (2017). God forskningssed.

\section{Appendix 1}

\section{Transkriberingsnyckel (efter Mondada, 2016).}

* * Blickar, gester och beskrivning av förkroppsligade handlingar markeras mellan

$++\quad$ två identiska symboler (en symbol per deltagare för blick respektive förkroppsligad handling)

$\circ \circ \quad$ och synkroniseras med hur länge talet sträcker sig.

*---> Handlingen fortsätter över påföljande rader

----> fram till samma symbol.

[ Överlappande tal

NAMN vem talar

namn vem gör

(2.0) tid i sekunder

(.) mikropaus

: förlängd stavelse 